University of Massachusetts Amherst

ScholarWorks@UMass Amherst

Chemistry Department Faculty Publication Series

Chemistry

2007

\title{
Influences of cadmium and zinc interaction and humic acid on metal accumulation in Ceratophyllum demersum
}

S Bunluesin

P Pokethitiyook

GR Lanza

JF Tyson

M Kruatrachue

See next page for additional authors

Follow this and additional works at: https://scholarworks.umass.edu/chem_faculty_pubs

Part of the Chemistry Commons

\section{Recommended Citation}

Bunluesin, S; Pokethitiyook, P; Lanza, GR; Tyson, JF; Kruatrachue, M; Xing, BS; and Upatham, S, "Influences of cadmium and zinc interaction and humic acid on metal accumulation in Ceratophyllum demersum" (2007). Water Air and Soil Pollution. 1012.

Retrieved from https://scholarworks.umass.edu/chem_faculty_pubs/1012 
Authors

S Bunluesin, P Pokethitiyook, GR Lanza, JF Tyson, M Kruatrachue, BS Xing, and S Upatham 


\title{
Influences of Cadmium and Zinc Interaction and Humic Acid on Metal Accumulation in Ceratophyllum Demersum
}

\author{
Sushera Bunluesin • Prayad Pokethitiyook • \\ Guy R. Lanza • Julian F. Tyson • \\ Maleeya Kruatrachue • Baoshan Xing • \\ Suchart Upatham
}

\begin{abstract}
Interactions between $\mathrm{Zn}$ and $\mathrm{Cd}$ on the accumulation of these metals in coontail, Ceratophyllum demersum were studied at different metal concentrations. Plants were grown in nutrient solution containing $\mathrm{Cd}\left(0.05-0.25 \mathrm{mg} \mathrm{l}^{-1}\right)$ and $\mathrm{Zn}(0.5-$ $\left.5 \mathrm{mgl}^{-1}\right)$. High concentrations of $\mathrm{Zn}$ caused a significant decrease in $\mathrm{Cd}$ accumulation. In general, adding $\mathrm{Cd}$ solution decreased $\mathrm{Zn}$ accumulation in $C$. demersum except at the lowest concentration of $\mathrm{Zn}$ in which the $\mathrm{Zn}$ accumulation was similar to that without $\mathrm{Cd}$. $C$.
\end{abstract}

S. Bunluesin $\cdot$ P. Pokethitiyook $(\bowtie)$

Department of Biology, Faculty of Science,

Mahidol University, Bangkok 10400, Thailand

e-mail: scppg@mahidol.ac.th

G. R. Lanza

Environmental Science Program,

University of Massachusetts, Amherst, MA, USA

\section{J. F. Tyson}

Department of Chemistry, University of Massachusetts,

Amherst, MA, USA

M. Kruatrachue

Department of Biology, Faculty of Science,

Mahidol University International College,

Mahidol University, Bangkok 10400, Thailand

B. Xing

Department of Plant and Soil Science,

University of Massachusetts, Amherst, MA, USA

S. Upatham

Burapha University, Chonburi 20130, Thailand demersum could accumulate high concentrations of both $\mathrm{Cd}$ and $\mathrm{Zn}$. The influence of humic acid (HA) on $\mathrm{Cd}$ and $\mathrm{Zn}$ accumulation was also studied. HA had a significant effect on $\mathrm{Zn}$ accumulation in plants. $2 \mathrm{mg} \mathrm{l}^{-1}$ of $\mathrm{HA}$ reduced $\mathrm{Zn}$ accumulation at $1 \mathrm{mg} \mathrm{l}^{-1}$ level (from 2,167 to $803 \mathrm{mg} \mathrm{kg}^{-1}$ ). Cd uptake by plant tissue, toxicity symptoms and accumulation at 0.25 and $0.5 \mathrm{mg}$ $1^{-1}$, were reduced (from 515 to $154 \mathrm{mg} \mathrm{kg}^{-1}$ and from 816 to $305 \mathrm{mg} \mathrm{kg}^{-1}$, respectively) by addition of $2 \mathrm{mg}$ $1^{-1}$ of HA. Cd uptake reached a maximum on day 9 of treatment, while that of $\mathrm{Zn}$ was observed on day 15 . Long-term accumulation study revealed that HA reduced toxicity and accumulation of heavy metals.

Keyword cadmium . Ceratophyllum demersum . humic acid · interactions $\cdot$ zinc

\section{Introduction}

Toxic heavy metal contamination in soils, water and plants is of major importance due to its health effects on humans and other animals (Farmer \& Farmer, 2000; Pichtel, Kuroiwa, \& Sawyer, 2000). Cd and Zn are common industrial pollutants. Although some sources of pollution contaminate the environment exclusively with $\mathrm{Cd}$, most cases of $\mathrm{Cd}$ polluted soils represent situations of multiple metal pollution. Both $\mathrm{Cd}$ and $\mathrm{Zn}$ are harmful to plant at relatively low concentrations (Chakravarty \& Srivastava, 1992). The 
processing and subsequent release of $\mathrm{Zn}$ to the environment is normally accompanied by $\mathrm{Cd}$ pollution because $\mathrm{Zn}$ ores $(\mathrm{ZnS})$ generally contain $0.1 \%$ $5 \%$ and sometimes with even higher concentrations of $\mathrm{Cd}$ (Adriano, 1996). The association of $\mathrm{Cd}$ and $\mathrm{Zn}$ in the environment and their chemical similarity can lead to interaction between these two ions (McKenna, Chaney, \& Williams, 1993), resulting in the lowering of Cd toxicity (Wajda, Kutemozinska, \& Pilipowiez, 1989). Since $\mathrm{Cd}$ is a nonessential ion, it is toxic at a lower concentration than $\mathrm{Zn}$ (Chakravarty \& Srivastava, 1994). Consequently, the uptake and translocation of $\mathrm{Zn}$ by plants is higher than that of Cd (Srivastava \& Singha, 1989). They may be both antagonistic and synergistic, and their imbalanced reactions may cause a real chemical stress in plants (Kabata-Pandias, 2000).

Natural waters typically contain milligram per liter concentrations of dissolved organic matter (DOM) (Thurman, 1985). DOM largely controls dissolved metals (i.e., metals passing through $0.45 \mu \mathrm{m}$ filters) speciation (Florence, 1982). Numerous studies indicate that a large proportion of the trace metals found dissolved in natural waters are in the organic fraction (i.e., in the form of metal-DOM complexes) (Linnik, $2000)$. A major fraction of DOM in natural water ( $\sim 60 \%-70 \%$ of total dissolved organic carbon) is composed of humic substances which consist mainly of humic acid and fulvic acid. These are heterogenous, hardly separable, mixtures of polyelectrolytes with varying molecular sizes, substructures and functionalities (Stevenson, 1994).

The bioavailability and toxicity of some metals in natural surface waters are reduced by complexation with dissolved organic matter as Tubbing et al. (1994) have shown for $\mathrm{Cu}$. Freshwater humic acid was reported to reduce the sensitivity of Chlamydomonas reinhardtii to $\mathrm{Cu}$ (Garvey, Owen, \& Winner, 1991). Koukal, Guegen, Pardos, and Domonik (2003) studied the influence of humic substances on the toxic effects of $\mathrm{Cd}$ and $\mathrm{Zn}$ to the green alga (Pseudokirchnerriella subcapitata). They found that humic acids markedly decreased $\mathrm{Cd}$ and $\mathrm{Zn}$ bioavailability and toxicity to $P$. subcapitata. In contrast, fulvic acid did not show any apparent effect. They also suggested that humic acids would have preponderant role in regulation of $\mathrm{Zn}$ and $\mathrm{Cd}$ bioavailability and toxicity in natural aquatic environments.

Aquatic plants are particularly important organisms for heavy metal uptake studies, since the analysis of plants can give an indication of the water environment to which they have been exposed. Ceratophyllum demersum, a free floating rootless macrophyte, has been demonstrated as a $\mathrm{Cd}^{2+}$ hyperaccumulator species under field conditions (Rai, Sinha, Tripathy, \& Chandra, 1995) and it is reported to be a powerful scavenger of $\mathrm{Cd}$ at low concentrations (Ornes \& Sajwan, 1993). The objective of this work was to study the effect of $\mathrm{Cd}$ and $\mathrm{Zn}$ interaction on heavy metals accumulation in $C$. demersum. In addition, since there was also very limited information on the interactive effects of humic acid and heavy metals $(\mathrm{Cd}$ and $\mathrm{Zn}$ ) on aquatic plants, another objective of this study was to determine the interactive effects of combined $\mathrm{Cd}$ and $\mathrm{Zn}$ and humic acid on metals accumulation in C. demersum.

\section{Materials and Methods}

\subsection{Interaction of zinc and cadmium on metal accumulation}

Ceratophyllum demersum plants were collected from Lake Warner, MA, USA. Plants were acclimatized in $30 \%$ Hoagland's nutrient solution at $\mathrm{pH} 5.5$ [macronutrients: $\mathrm{KH}_{2} \mathrm{PO}_{4}, \mathrm{KNO}_{3}, \mathrm{Ca}\left(\mathrm{NO}_{3}\right)_{2}$ and $\mathrm{MgSO}_{4}$; micronutrient: $\mathrm{H}_{3} \mathrm{BO}_{3}, \mathrm{MnCl}_{2} \cdot 6 \mathrm{H}_{2} \mathrm{O}, \mathrm{ZnSO}_{4} \cdot 7 \mathrm{H}_{2} \mathrm{O}$ ( $\mathrm{Zn}$ concentration $=0.015 \mathrm{mg} \mathrm{l}^{-1}$ ), $\mathrm{CuSO}_{4} \cdot 5 \mathrm{H}_{2} \mathrm{O}$ and $\mathrm{H}_{2} \mathrm{MoO}_{4}$; $\left.\mathrm{Fe}-\mathrm{EDTA}\right]$. Cultures were illuminated for $12 \mathrm{~h} /$ day using white fluorescent light in a thermostatically controlled greenhouse at $25 \pm 5^{\circ} \mathrm{C}$. Plant materials, approximately $10 \mathrm{~g}$ fresh weight, were transferred to a $700-\mathrm{ml}$ polyethylene plastic container with $600 \mathrm{ml}$ of $30 \%$ Hoagland's nutrient solution. Standard solutions of $\mathrm{Cd}\left[\mathrm{Cd}\left(\mathrm{NO}_{3}\right)_{2} \cdot 4 \mathrm{H}_{2} \mathrm{O}\right]$ and $\mathrm{Zn}$ $\left[\mathrm{Zn}\left(\mathrm{NO}_{3}\right)_{2} \cdot 6 \mathrm{H}_{2} \mathrm{O}\right]$ (Analytical grade, Aldrich, USA.) were added to the nutrient solution on the day of plant transfer. Two Cd levels $\left(0.05,0.25 \mathrm{mg} \mathrm{l}^{-1}\right)$ and three $\mathrm{Zn}$ levels $\left(0.5,1.0,5.0 \mathrm{mg}^{-1}\right)$ were arranged in two experiments. Experiment 1.1 (with five treatments) was intended to evaluate the effects of increasing metal levels on metal accumulation when plants were separately exposed to $\mathrm{Cd}$ and $\mathrm{Zn}$ (Table I). Experiment 1.2 (with three treatments) investigated the effects of $\mathrm{Cd}-\mathrm{Zn}$ interactions on metal accumulation (Table I). The untreated group was served as a control. There were three replicates per each treatment. The plants were kept under controlled con- 
Table I Experimental design showing the metal concentrations used in the experiment on interaction of $\mathrm{Zn}$ and $\mathrm{Cd}$ and metal accumulation

\begin{tabular}{|c|c|c|c|c|c|}
\hline \multirow{2}{*}{$\frac{\text { Set }}{1}$} & \multicolumn{2}{|l|}{ Metals } & \multicolumn{3}{|c|}{ Concentration $\left(\mathrm{mg} \mathrm{l}^{-1}\right)$} \\
\hline & $\mathrm{Cd}$ & Untreated group & 0.05 & 0.25 & \\
\hline 2 & $\mathrm{Zn}$ & Untreated group & 0.5 & 1.0 & 5.0 \\
\hline 3 & $\mathrm{Cd}+\mathrm{Zn}$ & Untreated group & $0.25+0.5$ & $0.05+1.0$ & $0.25+5.0$ \\
\hline
\end{tabular}

ditions. After 15 days, whole plant samples from each treatment were separately harvested, rinsed with deionized water and oven dried at $105^{\circ} \mathrm{C}$ overnight. Then, $0.03 \mathrm{~g}$ of these dry plant materials were analyzed for metal contents by acid-digestion method. Toxicity symptoms were observed for each treatment. All equipments used in this study were immersed with $10 \%$ nitric acid and rinsed with distilled water to remove adhering metal ions.

\subsection{Influence of humic acid on metal accumulation}

For the study of the influence of humic acid (HA) on the heavy metals accumulation, HA isolated from a peat (Michigan, USA) was used in this study by the methods described by Velthorst, Nakken-Brameijer, and Mulder (1999). Chemical properties of humic acid are listed in Table II. Elemental analysis $(\mathrm{C}, \mathrm{H}, \mathrm{N}, \mathrm{O})$ was performed on a Perkin Elmer 2000 instrument and the results were presented on a dry and ash free basis. Total acidity and functional group analysis were established by standard titration methods as described by Stevenson (1994). Humic acid stock solution was daily prepared at $1,000 \mathrm{mg}^{-1}$ with deionized water, with addition of $1 \mathrm{M} \mathrm{NaOH}$. It was diluted to a final humic acid concentration of $2 \mathrm{mg} \mathrm{HA} \mathrm{l}^{-1}$ with a Hoagland's nutrient solution. Plant materials, $C$. demersum, approximately $10 \mathrm{~g}$ fresh weight, were transferred to a 700-ml plastic container with $600 \mathrm{ml}$ of $30 \%$ Hoagland's nutrient solution and the required

Table II Chemical properties of humic acid isolated from Michigan peat

\begin{tabular}{ll}
\hline Element & \\
\hline $\mathrm{C} \%$ & $46.6^{\mathrm{a}}$ \\
$\mathrm{H} \%$ & $4.3^{\mathrm{a}}$ \\
$\mathrm{N} \%$ & $2.6^{\mathrm{a}}$ \\
$\mathrm{O} \%$ & $46.5^{\mathrm{a}}$ \\
Total acidity (meq/g) & $7.6 \pm 0.06$ \\
$\mathrm{COOH}-(\mathrm{meq} / \mathrm{g})$ & $4.3 \pm 0.01$ \\
Phenolic OH- (meq/g) & $3.3 \pm 0.07$ \\
\hline
\end{tabular}

${ }^{\mathrm{a}}$ Results presented on a dry and ash free basis. concentrations of metals and humic acid. Two $\mathrm{Cd}$ levels $\left(0.25,0.5 \mathrm{mg} \mathrm{l}^{-1}\right)$, two $\mathrm{Zn}$ levels $(1.0,5.0 \mathrm{mg}$ $\left.1^{-1}\right)$ and one level of HA $\left(2 \mathrm{mg} \mathrm{l}^{-1}\right)$ were arranged in three experiments. Experiment 2.1 (with four treatments) was intended to evaluate the effects of HA on $\mathrm{Cd}$ accumulation at various concentrations of $\mathrm{Cd}$ (Table III). Experiment 2.2 (with four treatments) was to investigate the effects of HA on $\mathrm{Zn}$ accumulation at various concentrations of $\mathrm{Zn}$ (Table III). Experiment 2.3 (with four treatments) was designed to evaluate the effects of $\mathrm{HA}$ on $\mathrm{Cd}$ and $\mathrm{Zn}$ accumulation at various mixed concentrations of $\mathrm{Cd}$ and $\mathrm{Zn}$ (Table III). The untreated groups were (1) plants that were not exposed to metals and HA; and (2) plants that were exposed to $2 \mathrm{mg}^{-1} \mathrm{HA}$. There were six replicates per treatment. Plants were kept under controlled conditions. After 15 days, plant samples were separately harvested, oven dried at $105^{\circ} \mathrm{C}$ overnight, and $0.03 \mathrm{~g}$ dry plant materials were analyzed for metal contents by acid-digestion method. Toxicity symptoms were observed for each treatment.

\subsection{Uptake rate study}

For the metal uptake rate in $C$. demersum, plant samples (approximately $30 \mathrm{~g}$ fresh weight) were separately cultured in $0.5 \mathrm{mg} \mathrm{l}^{-1}$ of $\mathrm{Zn}$ and $0.25 \mathrm{mg}$ $1^{-1}$ of $\mathrm{Cd}$ for 15 days. Every 3 days, approximately $3 \mathrm{~g}$ fresh weight of plant samples were taken from the treated plants and rinsed with deionized water. Treated plants were acid-digested for metal determination. The influence of humic acid on metal uptake rate was also studied. $C$. demersum was treated with $\mathrm{Cd}\left(0.25 \mathrm{mg} \mathrm{l}^{-1}\right), \mathrm{Zn}\left(0.5 \mathrm{mg} \mathrm{l}^{-1}\right)$ and humic acid $\left(2 \mathrm{mg} \mathrm{l}^{-1}\right)$ for 21 days. Every 3 days, approximately $0.3 \mathrm{~g}$ fresh weight of the control (heavy metals and humic acid free) and treated plants were collected and analyzed for metal contents by acidsss-digestion method. In addition, during the first three days treated plants were harvested four times a day. The harvested periods of the first 3 days are as follows: 8.00 A.M., 12.00 P.M., 4.00 P.M. and 8.00 P.M.. The pHs of nutrient 
Table III Experimental design showing the metal and humic acid concentrations used in the experiment on influence of HA on metal accumulation

\begin{tabular}{lllll}
\hline Set & $\begin{array}{l}\text { Metal and } \\
\text { Humic Acid }\end{array}$ & $\begin{array}{l}\text { Concentration } \\
\left(\mathrm{mg} \mathrm{l}^{-1}\right)\end{array}$ & & \\
\hline 1 & Cd+HA & $0+0^{\mathrm{a}}$ & $0.25+0$ & $0.5+0$ \\
& & $0+2^{\mathrm{b}}$ & $0.25+2$ & $0.5+2$ \\
2 & $\mathrm{Zn}+\mathrm{HA}$ & $0+0$ & $1+0$ & $5+0$ \\
& & $0+2$ & $1+2$ & $5+2$ \\
3 & $\mathrm{Cd}+\mathrm{Zn}+\mathrm{HA}$ & $0+0+0^{\mathrm{c}}$ & $0.25+1+0$ & $0.5+5+0$ \\
& & & $0.25+1+2$ & $0.5+5+2$
\end{tabular}

${ }^{\mathrm{a}} 0+0$ means plants were treated with metal ions at $0 \mathrm{mg} \mathrm{l}^{-1}$ and $\mathrm{HA}$ at $0 \mathrm{mg} \mathrm{l}^{-1}$.

${ }^{\mathrm{b}} 0+2$ means plants were treated with metal ions at $0 \mathrm{mg}^{-1}$ and $\mathrm{HA}$ at $2 \mathrm{mg} \mathrm{l}^{-1}$.

${ }^{\mathrm{c}} 0+0+0$ means plants were treated with Hoagland's nutrient solution.

solutions were measured at time zero $(\mathrm{pH} \mathrm{5.5)}$ and every 3 days during the experiment.

\subsection{Determination of metal content}

Dried plant materials (from Sections 2.1. and 2.2.) and fresh plant samples (from Section 2.3.) were acid digested with $3: 1 \mathrm{ml} \mathrm{HNO}_{3} / \mathrm{H}_{2} \mathrm{O}_{2}$ by microwave digestion system from CEM-MDS-2100. The digested solution was adjusted to $25 \mathrm{ml}$ by a volumetric flask and analyzed for $\mathrm{Cd}$ and $\mathrm{Zn}$ content. $\mathrm{Zn}$ was determined by flame atomic absorption spectrophotometry (FAAS). A Perkin-Elmer Model 1100B double beam atomic absorption spectrophotometer with a deuterium background correction (Perkin-Elmer Corp., Norwalk, CT, USA) was used. The $\mathrm{Zn}$ hollow cathode lamp current was $5 \mathrm{~mA}$ and the monochromator was set at wavelength of $213.9 \mathrm{~nm}$. For $\mathrm{Cd}$ analysis, the $\mathrm{Cd}$ hollow cathode lamp current was $3 \mathrm{~mA}$. The monochromator was set at wavelength of $228.8 \mathrm{~nm}$ with $0.7 \mathrm{~nm}$ spectral bandpass. Cd concentrations above $0.1 \mathrm{mg} \mathrm{l}^{-1}$ were also analyzed by FAAS and below that level by AAS equipped with graphite furnace. A Perkin-Elmer Model 4100ZL Zeeman corrected electrothermal atomic absorption spectrophotometer (ETAAS) interfaced with a digital $316 \times$ work station, and controlled using Perkin-Elmer Gem software (version 7.2.1) was used. The method of standard addition was used to correct the matrix interferences.

\subsection{Statistical analysis}

Statistical analyses were carried out using SPSS for Windows program. The mean values of metal accumulation were calculated and subjected to analysis of variance (ANOVA) using two-way ANOVA and Least Significant Difference (LSD) methods after analysis as the homogeneity of variance.

\section{Results}

3.1 Interaction of zinc and cadmium on metal accumulation

Table IV shows the interaction of $\mathrm{Cd}$ and $\mathrm{Zn}$ on metal accumulation. The untreated plants showed relatively small amount of both metals $(0.10 \mathrm{mg} / \mathrm{kg}$ for $\mathrm{Cd}$ and $166 \mathrm{mg} / \mathrm{kg}$ for $\mathrm{Zn}$ ). Because $\mathrm{Zn}$ is required for several metabolic functions in plants, it was supplied in nutrient solution as a micronutrient. In the group of plants treated with $\mathrm{Cd}$ alone, the increase of $\mathrm{Cd}$ concentration in the nutrient solution significantly increased $(P<0.05) \mathrm{Cd}$ accumulation. The maximum accumulation was found in plants treated with $0.25 \mathrm{mg} \mathrm{l}^{-1} \mathrm{Cd}(440 \mathrm{mg} / \mathrm{kg})$ after 15 days. No toxicity symptoms were found in plants treated with $0.05 \mathrm{mg} \mathrm{l}^{-1} \mathrm{Cd}$, whereas at $0.25 \mathrm{mg} \mathrm{l}^{-1} \mathrm{Cd}$ plants showed mild toxicity symptoms, i.e., chlorosis. Similarly, in groups of plants treated with $\mathrm{Zn}$ alone,

Table IV The accumulation of $\mathrm{Zn}$ and $\mathrm{Cd}$ in $C$. demersum treated with different concentrations of $\mathrm{Zn}$ and $\mathrm{Cd}$ for 15 days

\begin{tabular}{|c|c|c|c|}
\hline \multicolumn{2}{|c|}{$\begin{array}{l}\text { Metal Concentration } \\
\left(\mathrm{mg} \mathrm{^{-1 } )}\right.\end{array}$} & \multicolumn{2}{|c|}{$\begin{array}{l}\text { Metal Accumulation } \\
(\mathrm{mg} / \mathrm{kg} \mathrm{dw})\end{array}$} \\
\hline $\mathrm{Cd}$ & $\mathrm{Zn}$ & $\overline{\mathrm{Cd}}$ & $\mathrm{Zn}$ \\
\hline 0 & 0 & $0.10 \pm 0.01^{\mathrm{a}}$ & $166 \pm 24^{\mathrm{a}}$ \\
\hline 0.05 & 0 & $70 \pm 5^{\mathrm{b}}$ & $175 \pm 38^{\mathrm{a}}$ \\
\hline 0.25 & 0 & $440 \pm 52^{\mathrm{c}}$ & $191 \pm 24^{\mathrm{a}}$ \\
\hline 0 & 0.5 & $0.13 \pm 0.02^{\mathrm{a}}$ & $424 \pm 76^{\mathrm{b}}$ \\
\hline 0 & 1.0 & $0.23 \pm 0.1^{\mathrm{a}}$ & $1,804 \pm 182^{\mathrm{d}}$ \\
\hline 0 & 5.0 & & \\
\hline 0.25 & 0.5 & $586 \pm 86^{\mathrm{d}}$ & $463 \pm 77^{\mathrm{b}}$ \\
\hline 0.05 & 1.0 & $91 \pm 69^{b}$ & $764 \pm 445^{\mathrm{c}}$ \\
\hline 0.25 & 5.0 & & \\
\hline
\end{tabular}

Mean \pm S.D.; $\mathrm{n}=3$.

Different letters in the same column indicate that differences between untreated and treated $C$. demersum are significant at the 0.05 level. 
the increase of $\mathrm{Zn}$ concentration significantly increased $(P<0.05) \mathrm{Zn}$ accumulation. Plants treated with $1 \mathrm{mg} \mathrm{l}^{-1} \mathrm{Zn}$ showed the maximum content $(1,804 \mathrm{mg} / \mathrm{kg})$. Treated plants did not show any toxicity symptoms at 0.5 and $1.0 \mathrm{mg} \mathrm{l}^{-1} \mathrm{Zn}$. $\mathrm{Zn}$ concentration of $5 \mathrm{mg} \mathrm{l}^{-1}$ caused severe toxicity symptoms in plants, such as chlorosis and tissue dissolution. Plants died after 7 days of treatment. The interaction treatments showed a significant increase $(P<0.05)$ of $\mathrm{Cd}$ content in plant tissue when $0.5 \mathrm{mg}$ $\mathrm{l}^{-1} \mathrm{Zn}$ was added (Table IV). At $0.05 \mathrm{mg} \mathrm{l}^{-1} \mathrm{Cd}$, the addition of $\mathrm{Zn}\left(1.0 \mathrm{mg} \mathrm{1^{-1 }}\right)$ did not cause any significant increase of $\mathrm{Cd}$ content $(91 \mathrm{mg} / \mathrm{kg})$, when compared to the $\mathrm{Cd}$ treatment without $\mathrm{Zn}(70 \mathrm{mg} / \mathrm{kg})$. Similarly, the adding of $\mathrm{Cd}\left(0.25 \mathrm{mg} \mathrm{l}^{-1}\right)$ did not cause any significant increase in $\mathrm{Zn}$ content $(463 \mathrm{mg} /$ $\mathrm{kg}$ ), when compared to the $\mathrm{Zn}$ treatment without $\mathrm{Cd}$ (424 mg/kg). However, the adding of $0.05 \mathrm{mg} \mathrm{l}^{-1} \mathrm{Cd}$ caused a significant decrease in $\mathrm{Zn}$ content at $1.0 \mathrm{mg}$ $1^{-1} \mathrm{Zn}(1,804 \mathrm{mg} / \mathrm{kg}$ without $\mathrm{Cd}, 764 \mathrm{mg} / \mathrm{kg}$ with $\mathrm{Cd}$; Table IV) $(P<0.05)$. Plants showed severe toxicity symptoms and died in every treatment containing $5 \mathrm{mg} \mathrm{l}^{-1} \mathrm{Zn}$ (Table IV).

\subsection{Influence of humic acid on metal accumulation}

Table $\mathrm{V}$ shows $\mathrm{Zn}$ accumulation in $C$. demersum treated with $\mathrm{Zn}$ and HA for 15 days. The untreated plants ( $\mathrm{Zn}$ and HA free) and those treated with HA alone contained 255 and $117 \mathrm{mg} / \mathrm{kg} \mathrm{Zn}$, respectively. This may result from the $\mathrm{Zn}$ added as a micronutrient. $\mathrm{Zn}$ and humic acid had significant effects on $\mathrm{Zn}$ accumulation in C. demersum (Table V). At a concentration of $1 \mathrm{mg} \mathrm{l}^{-1}$ of $\mathrm{Zn}$, plants treated with $\mathrm{Zn}$ and HA had a significantly lower $\mathrm{Zn}$ content

Table $\mathbf{V} \mathrm{Zn}$ accumulation in C. demersum treated with $\mathrm{Zn}$ and humic acid at different concentrations for 15 days

\begin{tabular}{lll}
\hline \multicolumn{2}{l}{ Concentration $\left(\mathrm{mg} \mathrm{1}^{-1}\right)$} & \\
\cline { 1 - 2 } $\mathrm{Zn}$ & Humic Acid & \\
\hline 0 & 0 & $255 \pm 29^{\mathrm{b}}$ \\
0 & 2 & $117 \pm 18^{\mathrm{a}}$ \\
1 & 0 & $2,167 \pm 474^{\mathrm{d}}$ \\
1 & 2 & $803 \pm 134^{\mathrm{c}}$ \\
5 & 0 & \\
5 & 2 & $5,875 \pm 710^{\mathrm{e}}$ \\
\hline
\end{tabular}

Mean \pm S.D.; $\mathrm{n}=6$.
Table VI Cd accumulation in $C$. demersum treated with $\mathrm{Cd}$ and humic acid at different concentrations for 15 days

\begin{tabular}{lll}
\hline \multicolumn{2}{l}{ Concentration $\left(\mathrm{mg} \mathrm{l}^{-1}\right)$} & Cd Accumulation $(\mathrm{mg} / \mathrm{kg} \mathrm{dw})$ \\
\hline Cd & Humic Acid & \\
\hline 0 & 0 & $0.07 \pm 0.03^{\mathrm{a}}$ \\
0 & 2 & $0.09 \pm 0.05^{\mathrm{a}}$ \\
0.25 & 0 & $515 \pm 85^{\mathrm{d}}$ \\
0.25 & 2 & $154 \pm 16^{\mathrm{b}}$ \\
0.5 & 0 & $816 \pm 60^{\mathrm{e}}$ \\
0.5 & 2 & $305 \pm 40^{\mathrm{c}}$ \\
\hline
\end{tabular}

Mean \pm S.D.; $\mathrm{n}=6$.

$(803 \mathrm{mg} / \mathrm{kg}$ ) compared to those treated with $\mathrm{Zn}$ alone $(2,167 \mathrm{mg} / \mathrm{kg})(P<0.05)$. In addition, no toxicity symptoms were found in treated plants from both treatments. A concentration of $5 \mathrm{mg} \mathrm{l}^{-1} \mathrm{Zn}$ without HA was very toxic to plants as seen in the form of chlorosis and tissue dissolution. In this treatment plants died on the 7th day. Meanwhile, no toxicity symptoms were observed in plants treated with $5 \mathrm{mg}$ $1^{-1}$ of $\mathrm{Zn}$ and $2 \mathrm{mg} \mathrm{l}^{-1}$ of HA and they showed the highest accumulation of $\mathrm{Zn}(5,875 \mathrm{mg} / \mathrm{kg})$ (Table V).

Similar trends were found in plants treated with $\mathrm{Cd}$ and HA. At a low level of $\mathrm{Cd}\left(0.25 \mathrm{mg} \mathrm{l}^{-1}\right), \mathrm{Cd}$ content in $C$. demersum treated with $\mathrm{Cd}$ and $\mathrm{HA}$ $(154 \mathrm{mg} / \mathrm{kg})$ was significantly lower $(P<0.05)$ than that in plants treated with $\mathrm{Cd}$ alone $(515 \mathrm{mg} / \mathrm{kg}$; Table VI). A high level of $\mathrm{Cd}\left(0.5 \mathrm{mg} \mathrm{l}^{-1}\right)$ without HA caused slight toxic effects to plants and significantly higher $\mathrm{Cd}$ content $(816 \mathrm{mg} / \mathrm{kg})$ in plant tissues compared to those treated with Cd and HA (305 mg/ $\mathrm{kg}$; $P<0.05$; Table VI). No toxicity symptoms were observed in either treatment which received HA (2 mg/l).

The combination of $\mathrm{Cd}$ and $\mathrm{Zn}$ and $\mathrm{HA}$ had significant effects $(P<0.05)$ on $\mathrm{Zn}$ and $\mathrm{Cd}$ accumulation in plant tissues (Table VII). The untreated plants (Cd and HA free) contained relatively small amounts of both metals $(0.13 \mathrm{mg} / \mathrm{kg}$ for Cd and $393 \mathrm{mg} / \mathrm{kg}$ for $\mathrm{Zn}$, respectively). Plants exposed to high levels of $\mathrm{Cd}$ and $\mathrm{Zn}\left(0.5\right.$ and $5 \mathrm{mg} \mathrm{l}^{-1}$, respectively) showed severe toxicity symptoms and died within 3 days. Plants accumulated the highest content of $\mathrm{Cd}(659 \mathrm{mg} / \mathrm{kg})$ and $\mathrm{Zn}(8,216 \mathrm{mg} / \mathrm{kg})$ after 15 days. Plants exposed to a low level of $\mathrm{Cd}$ and $\mathrm{Zn}\left(0.25\right.$ and $1.0 \mathrm{mg} \mathrm{l}^{-1}$, respectively) combined with HA showed significantly lower Cd and Zn content (Cd 204, Zn 973 mg/kg) 
Table VII The $\mathrm{Zn}$ and $\mathrm{Cd}$ accumulations in C. demersum treated with humic acid and combination of $\mathrm{Cd}$ and $\mathrm{Zn}$ at different concentrations for 15 days

Mean \pm S.D.; $\mathrm{n}=6$.

compared to those that did not receive HA (Cd 406, Zn $1,737 \mathrm{mg} / \mathrm{kg} ; P<0.05$; Table VII). Mild toxicity symptoms were observed in the treatment containing only $\mathrm{Cd}$ and $\mathrm{Zn}$ at a low concentration.

\begin{tabular}{|c|c|c|c|c|}
\hline \multicolumn{2}{|c|}{ Concentration (mg l$\left.{ }^{-1}\right)$} & \multirow[b]{2}{*}{ HA } & \multicolumn{2}{|c|}{ Metal Accumulation (mg/kg dw) } \\
\hline $\mathrm{Cd}$ & $\mathrm{Zn}$ & & $\mathrm{Cd}$ & $\mathrm{Zn}$ \\
\hline 0 & 0 & 0 & $0.13 \pm 0.03^{\mathrm{a}}$ & $393 \pm 137^{\mathrm{a}}$ \\
\hline 0.25 & 1 & 0 & $406 \pm 84^{c}$ & $1,737 \pm 372^{\mathrm{c}}$ \\
\hline 0.25 & 1 & 2 & $204 \pm 31^{\mathrm{b}}$ & $973 \pm 70^{\mathrm{b}}$ \\
\hline 0.5 & 5 & 0 & & \\
\hline 0.5 & 5 & 2 & $659 \pm 128^{\mathrm{c}}$ & $8,216 \pm 1347^{\mathrm{d}}$ \\
\hline
\end{tabular}

3.3 Metal uptake rate

The uptake rate of $\mathrm{Zn}$ and $\mathrm{Cd}$ in $C$. demersum at different durations is shown in Figure 1 . $\mathrm{Zn}$ content in
Figure 1 The accumulation of $\mathrm{Zn}$ (a) and $\mathrm{Cd}$ (b) in $C$. demersum treated separately with $0.5 \mathrm{mg} \mathrm{l}^{-1}$ of $\mathrm{Zn}$ and $0.25 \mathrm{mg}^{-1}$ of $\mathrm{Cd}$. Values are means \pm S.D. $(n=3)$.
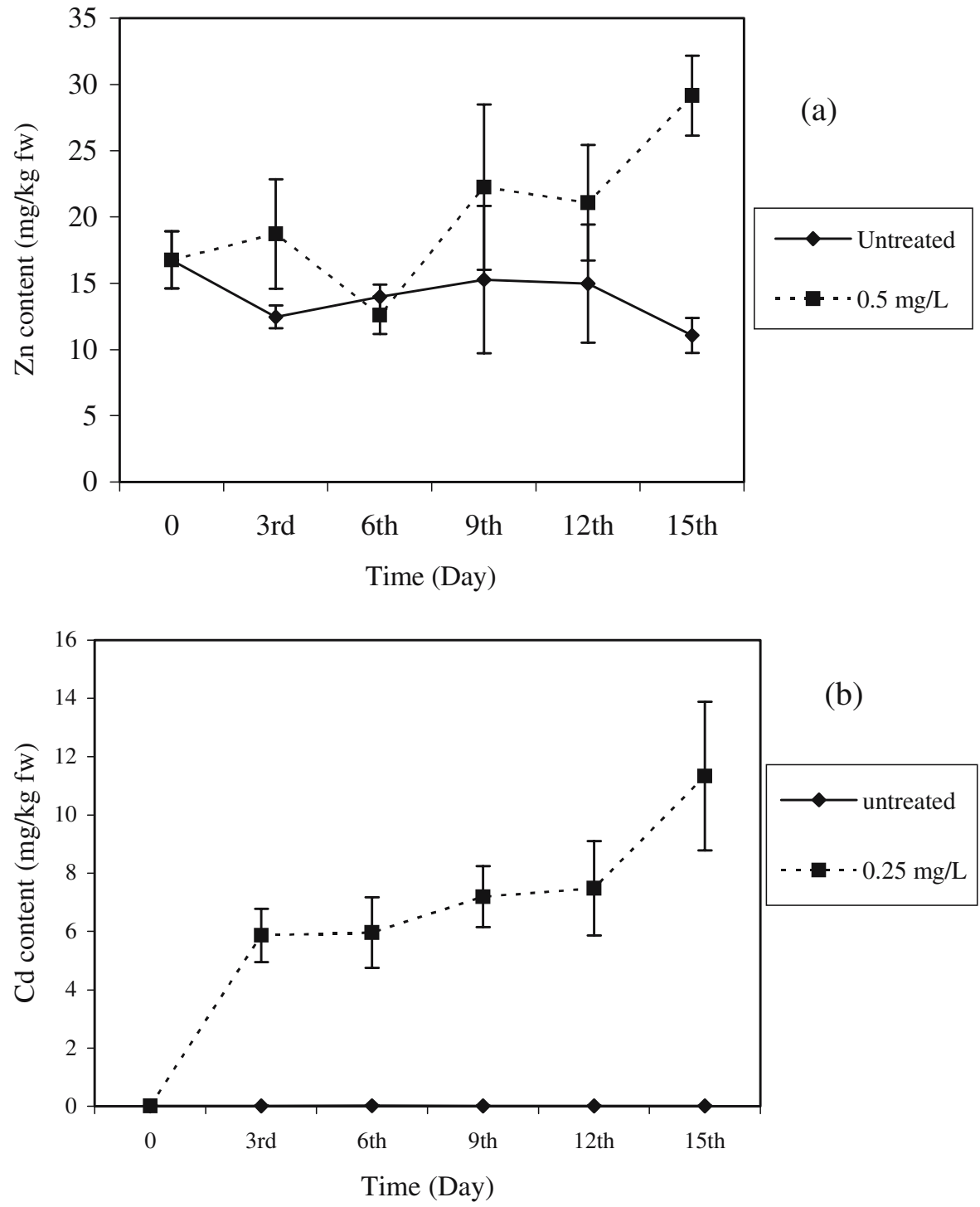
Figure 2 The Cd contents of $C$. demersum treated with $\mathrm{Cd}$ and humic acid at different time interval. Values are means \pm S.D. $(n=3)$.

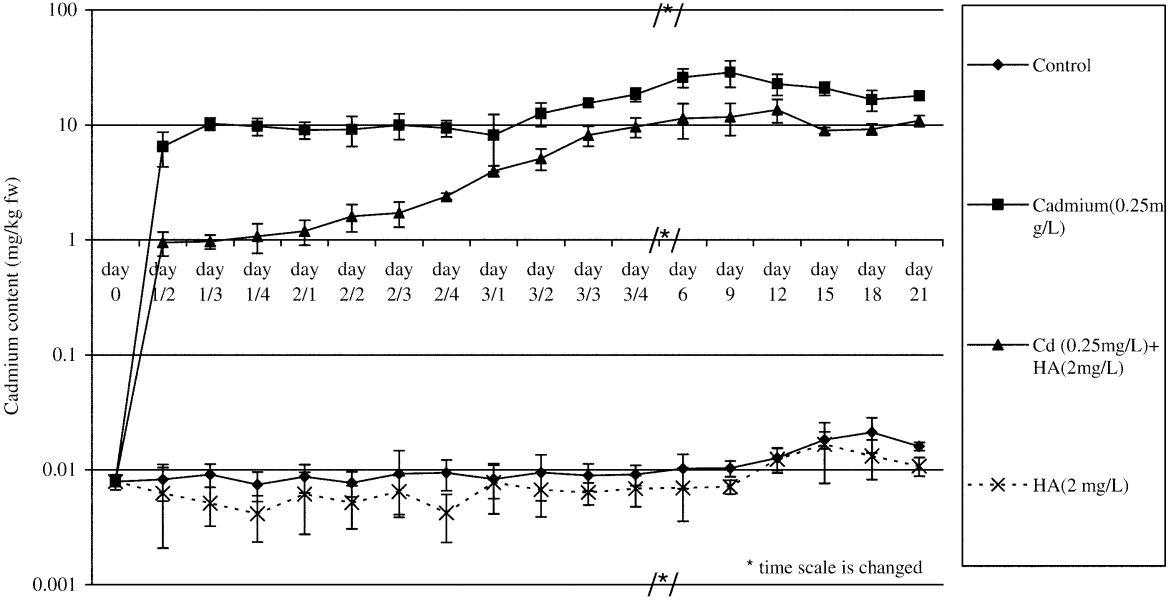

plant tissues increased with increasing exposure time. At $0.5 \mathrm{mg}^{-1}$ of $\mathrm{Zn}$, no toxicity symptoms were observed. $\mathrm{Zn}$ accumulation did not differ significantly until day 12. The highest $\mathrm{Zn}$ content was found on day 15 and was significantly greater $(P<0.05)$ from that of the untreated plants (Figure 1a). In $\mathrm{Cd}$ treatments $\left(0.25 \mathrm{mg} \mathrm{l}^{-1}\right.$ of $\left.\mathrm{Cd}\right), \mathrm{Cd}$ uptake by plants at day 3 was significantly different $(P<0.05)$ from that of day 0 . There was no significant difference in $\mathrm{Cd}$ accumulation from day 3 to day 12 . The highest $\mathrm{Cd}$ content was found on day 15 (Figure 1b). At this level, $\mathrm{Cd}$ did not cause any adverse effects on $C$. demersum.

Figure 2 shows the influence of HA on metal uptake rate. $\mathrm{Cd}$ content in $C$. demersum sharply increased after plants were placed into $0.25 \mathrm{mg} \mathrm{l}^{-1}$ of $\mathrm{Cd}$, whereas a more gradual increase was found in the treatment of $\mathrm{Cd}$ with $2 \mathrm{mg}^{-1} \mathrm{HA}$ until day 4 . At day 9, the Cd uptake in both treatments (with and without $\mathrm{HA}$ ) reached the maximum capacity. The $\mathrm{Cd}$ content in plants from the $\mathrm{Cd}$ alone treatment was significantly higher $(P<0.05)$ than that where treatment was combined with HA. In every treatment, there was an increase of $\mathrm{pH}$ of the nutrient solution throughout the experiment. The $\mathrm{pH}$ of nutrient solution containing HA ( $\mathrm{pH}$ 7.4) was higher than that of treatment without HA (pH 6.8).

$\mathrm{Zn}$ contents in $C$. demersum from the uptake rate study are shown in Figure 3. During the first three days, there was no significant difference in $\mathrm{Zn}$ accumulation between the treated and untreated plants. In plants supplied with $0.5 \mathrm{mg} \mathrm{l}^{-1}$ of $\mathrm{Zn}$ the highest $\mathrm{Zn}$ content was found on day 15. After that period, the $\mathrm{Zn}$ content in all treatments decreased. There was no significant difference in $\mathrm{Zn}$ accumulation between
Figure 3 The $\mathrm{Zn}$ contents of $C$. demersum treated with $\mathrm{Zn}$ and humic acid at different time intervals. Values are means \pm S.D. $(n=3)$.

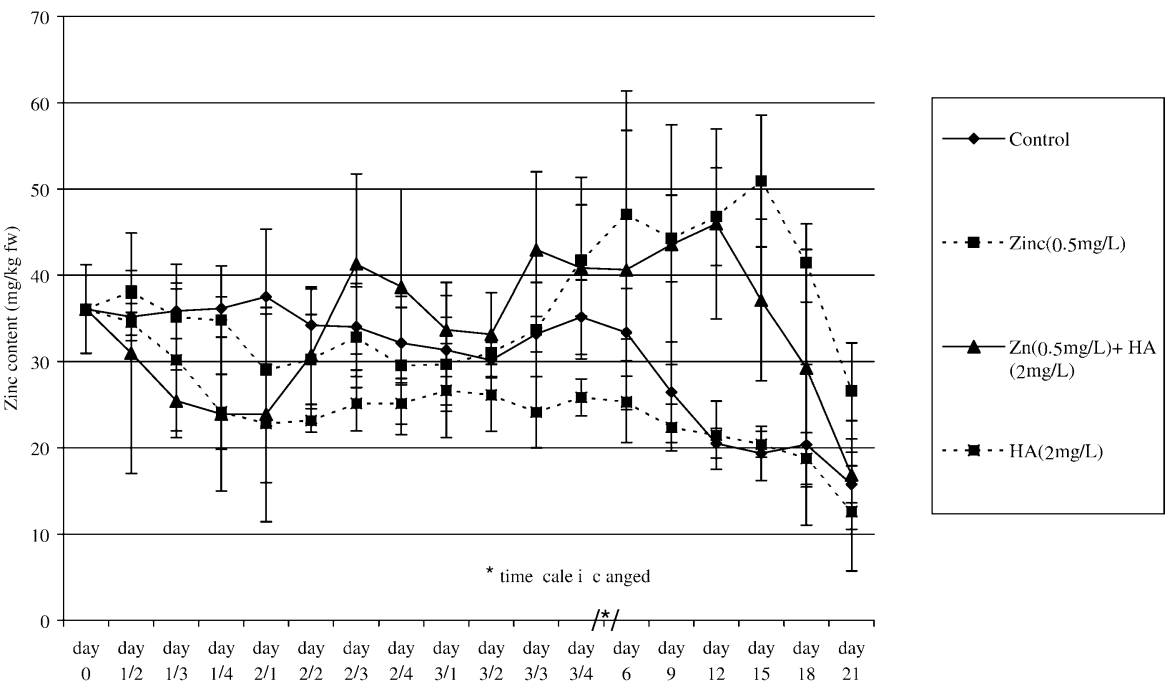


Figure 4 Effects of metals and humic acid on $\mathrm{pH}$ of treated solution at different time interval; $\mathrm{Cd}$ (a) and $\mathrm{Zn}$ (b). The initial $\mathrm{pH}$ of the growth medium was 5.5 .

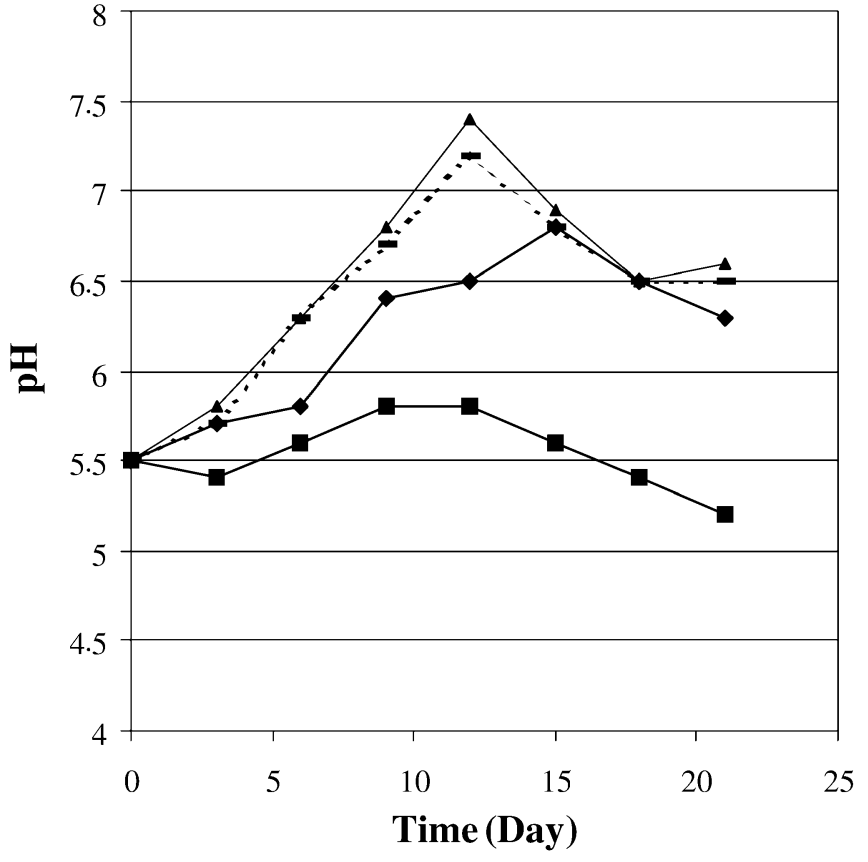

(a)

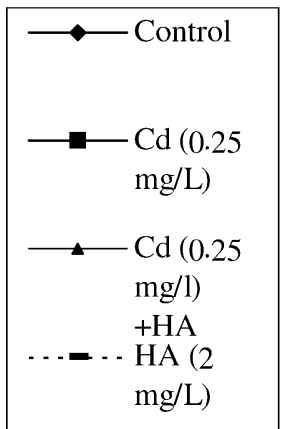

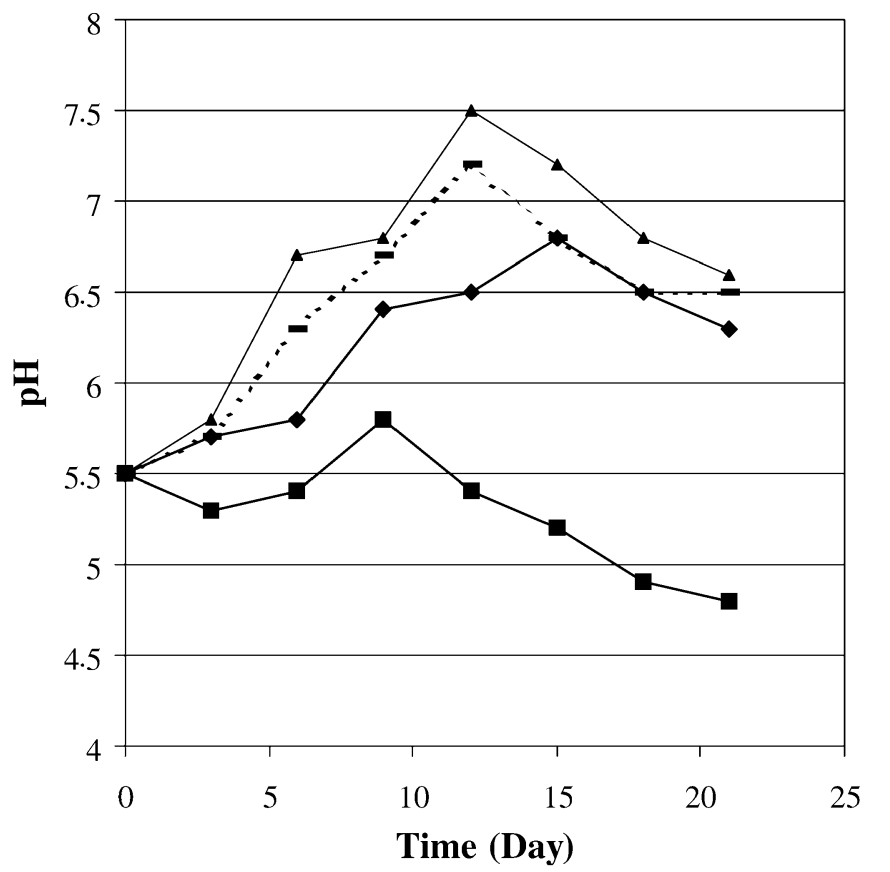

(b)

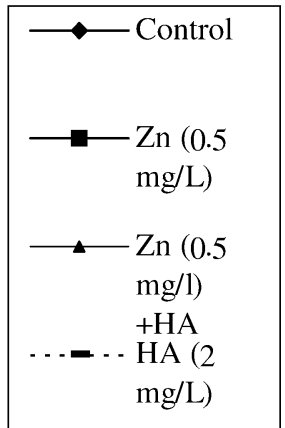

plants with and without $2 \mathrm{mg} \mathrm{l}^{-1}$ HA. A reduced uptake of $\mathrm{Zn}$ was found in HA-added treatments on day 1 . However, from day 2 onwards, the $\mathrm{Zn}$ contents in the plants in both treatments increased. The $\mathrm{pH}$ in every treatment increased gradually throughout the experiment (from 5.5 to 7.5 ).

\section{Discussion}

From our results, $\mathrm{Zn}$ at $5 \mathrm{mg} \mathrm{1}^{-1}$ was found very toxic to $C$. demersum, owing to the dual role of $\mathrm{Zn}$ as an essential microelement on the one hand and as toxic environmental pollutant on the other (Chakravarty \& 
Srivastava, 1997). The results indicate that the interactions between $\mathrm{Zn}$ and $\mathrm{Cd}$ on the accumulation of both metals in $C$. demersum were complex and dependent on the concentrations of those metals in growth medium. Turner (1973) observed that the effect of $\mathrm{Cd}$ treatments of leaf $\mathrm{Zn}$ concentrations depended on plant species, having a synergistic effect in some plant species and antagonistic effect in others. The results of the present study show a significant positive effect of $\mathrm{Zn}$ on the accumulation of $\mathrm{Cd}$ in $C$. demersum. The addition of $0.5 \mathrm{mg}^{-1} \mathrm{Zn}$ resulted in an increase of $\mathrm{Cd}$ content in plants at $0.25 \mathrm{mg} \mathrm{l}^{-1} \mathrm{Cd}$. A higher level of $\mathrm{Zn}\left(1 \mathrm{mg}^{-1}\right)$ did not increase $\mathrm{Cd}$ accumulation in treated plants at $0.05 \mathrm{mg}^{-1} \mathrm{Cd}$. At higher concentration the toxicity of $\mathrm{Zn}$ manifests itself, leading to synergistic action with $\mathrm{Cd}$; at lower concentration, $\mathrm{Zn}$, being an essential ion, was nontoxic to the plant, and could not interact with or lower the toxicity of Cd (Chakravarty \& Srivastava, 1997).

Our finding was that $\mathrm{Cd}$ had a slight negative effect on $\mathrm{Zn}$ accumulation in $C$. demersum. The accumulation of $\mathrm{Zn}$ at $1 \mathrm{mg} \mathrm{l}^{-1} \mathrm{Zn}$ was reduced when $0.05 \mathrm{mg} \mathrm{l}^{-1} \mathrm{Cd}$ was added. Meanwhile, when $0.25 \mathrm{mg}$ $1^{-1} \mathrm{Cd}$ was added, $\mathrm{Zn}$ content in treated plants did not change at $0.5 \mathrm{mg} \mathrm{l}^{-1} \mathrm{Zn}$. As $\mathrm{Zn}$ and $\mathrm{Cd}$ are chemically very similar, they can compete for binding and absorption sites in the plants (Hart, Welch, Noevell, \& Kochain, 2002). Lagerwerff and Biersdorf (1972) detected a decrease of $\mathrm{Cd}$ concentrations in radish leaves with $\mathrm{Zn}$ addition in plants grown at lower $\mathrm{Cd}$ concentrations but not at high $\mathrm{Cd}$. Some other published data (Cataldo \& Wildung, 1978; John, 1976) indicated that the effects of $\mathrm{Zn}$ on plant $\mathrm{Cd}$ uptake (similar to that of $\mathrm{Cd}$ on $\mathrm{Zn}$ uptake) also might depend on plant species, plant tissue, and external $\mathrm{Cd}$ and $\mathrm{Zn}$ concentration levels. Furthermore, Nan, Li, Zhang, and Cheng (2002) analyzed the Cd-Zn interaction mechanism in soil-crop system under actual field conditions. They concluded that the effects of the two metals were synergistic to each other, in which increasing $\mathrm{Cd}$ and $\mathrm{Zn}$ content in soils could increase the accumulation of $\mathrm{Zn}$ or $\mathrm{Cd}$ in the crops.

It was shown in the present study that $C$. demersum could accumulate high content of metals ( $\mathrm{Cd}$ and $\mathrm{Zn}$ ) when exposed to low concentrations ( $0.25 \mathrm{mg} \mathrm{l}^{-1} \mathrm{Cd}$; $1.0 \mathrm{mg} \mathrm{l}^{-1} \mathrm{Zn}$ ). The addition of HA resulted in a decrease of metal uptake capacity. Several studies reported on the decreases in metal uptake and toxicity caused by the addition of humic acid. Koukal et al. (2003) reported that the toxicity of $\mathrm{Cd}$ and $\mathrm{Zn}$ to green alga $P$. subcapitata, was significantly reduced in the presence of HA. Gardner and Al-Hamdani (1997) found that humic substances decreased toxicity of Al to Salvania minima. In addition, the administration of a high concentration of HA (160 $\mathrm{mg}^{-1}$ ) decreased Pb uptake by Lemna minor and brought about increases in total chlorophyll content, growth rate and multiplication rate compared with L. Figure Iminor treated with $\mathrm{Pb}$ nitrate alone (Kruatrachue et al., 2002). Hence, humic acid could reduce metal uptake and toxicity.

In general, the speciation of metals in natural water is a key determinant of their transport, retention and bioavailability. Humic substances are recognized to play a major role in metal speciation (Tipping, 2002). Gueguen et al. (2003) have used MINTEQA2 to calculate the model of $\mathrm{Cd}$ and $\mathrm{Zn}$ chemical speciation in Algal Assay Procedure (AAP) medium. They found that $\mathrm{Cd}$ and $\mathrm{Zn}$ free ion concentration decreased markedly in the presence of humic substances and they also reported that humic substances were much more important ligand for $\mathrm{Cd}$ and $\mathrm{Zn}$ than alga. As we have seen from the experiments that the toxicity and metal uptake capacity of treated $C$. demersum was reduced in the presence of HA. This may be resulted from the reduction of free metal ions available for the plants.

The binding of metal cations is strongly affected by $\mathrm{pH}$, firstly due to the competition between protons and metal cations for humic binding sites, and secondly because of cation hydrolysis (Tipping, 2002). The complex reaction of HA and heavy metal ions may be caused by the dissociation of protons from the carboxyl group of HA which starts at pH 6 . This association increases with increasing $\mathrm{pH}$ (Allard \& Arsenie, 1991). In this study, the $\mathrm{pH}$ of the culture medium with $\mathrm{HA}, \mathrm{Cd}$ and $\mathrm{Zn}$, was higher than that of the medium without HA. Presumably there was a dissociation of a proton from the carboxyl group in the HA which then formed complexes with metal ions. Ghosh and Banerjee (1997) studied the complexation of trace metals with HA. They reported that $\log \mathrm{K}$ was found to increase with the rise in $\mathrm{pH}$ of the medium. Increase in $\mathrm{pH}$ enhances the ionization of acidic functional groups and so the availability of active sites. A subsequent drive for the charge neutralization at the active sites with the metal binding promotes the complexation. The impact of $\mathrm{pH}$ on metal speciation was evaluated by Gueguen et al. 
(2003). They concluded that free metal ion was dominant from $\mathrm{pH}<7$ for $\mathrm{Cd}$ and $\mathrm{Zn}$. The calculation shows the tendency of $\mathrm{CO}_{3}^{2-}$ to the form complex in solution with metal in the natural $\mathrm{pH}$ range $(7<\mathrm{pH}<9)$. Thus, the change of $\mathrm{pH}$ in the range from 6 to 9 may strongly influence metal complexation.

The most abundant cation-binding groups in humic substances are carboxylate $\left(-\mathrm{COOH}^{-}\right)$, followed by phenolic - $\mathrm{OH}$. Less abundant are $\mathrm{N}$-containing groups and the group containing sulphur, which vary strongly and favor soft metal cations such as $\mathrm{Cd}^{2+}$. This trend has implications for the binding site strength and the competition among metals. For example, $\mathrm{Ca}^{2+}$, which is abundant in natural waters, may compete effectively with $\mathrm{Cd}^{2+}$ at carboxylate sites, but hardly at all sites with $\mathrm{S}$ as the donor atom (Tipping, 2002). From the study of Koukal et al. (2003), HA isolated from peat had a higher affinity for $\mathrm{Cd}$ than soil HA, whereas, $\mathrm{Zn}$ showed no preferences to any of the HA. The chemical properties of peat HA also show higher $\mathrm{S}$ content than that of soil HA. This reason may explain more stability of HA with $\mathrm{Cd}$ over $\mathrm{Zn}$ in this study.

\section{Conclusions}

Cd has a negative effect on $\mathrm{Zn}$ accumulation in $C$. demersum whereas low level of $\mathrm{Zn}$ has a positive effect on $\mathrm{Cd}$ uptake in experimental plants. Interaction between $\mathrm{Cd}$ and $\mathrm{Zn}$ are complex and dependent on the concentration of those metals in growth medium. HA clearly decreased $\mathrm{Cd}$ and $\mathrm{Zn}$ bioavailability and toxicity in treated plants due to the formation of complexes of HA with metal ions. However, the actual metal-humic acid interactions in soil and aquatic ecosystems may involve several simultaneous competing reactions. In addition, the results implied that HA has an important role in regulating $\mathrm{Zn}$ and $\mathrm{Cd}$ bioavailability and toxicity in natural aquatic environments.

Acknowledgments This work was supported by the Royal Golden Jubilee Ph.D. Program of the Thailand Research Fund, Bangkok, Thailand and University of Massachusetts, Amherst, MA, USA. The authors thank Dr. Waret Veerasai, Miss Wipharat Chuachuad, Miss Thippayawadee Kangkasomboon for their skillful technical assistance and also Asst. Prof. Philip D. Round for his English proof.

\section{References}

Adriano, D. C. (1996). Trace elements in the terrestrial environment (pp. 106-149). Berlin Heidelberg New York: Springer.

Allard, B., \& Arsenie, I. (1991). Abiotic reduction of mercury by humic substances in an aquatic system - An important process for the mercury cycle. Water, Air, and Soil Pollution, 56, 457-464.

Cataldo, D. A., \& Wildung, R. E. (1978). Soil and plant factors influencing the accumulation of heavy metals by plants. Environmental Health Perspective, 27, 149-159.

Chakravarty, B., \& Srivastava, S. (1992). Toxicity of some heavy metal in vivo and vitro in Helianthus annuus. Mutation Research, 283, 287-294.

Chakravarty, B., \& Srivastava, S. (1994). Response to cadmium toxicity during the in vitro growth in Arachis hypogaea. Bulletin of Environmental Contamination and Toxicology, 52, 749-755.

Chakravarty, B., \& Srivastava, S. (1997). Effect of cadmium and zinc interaction on metal uptake and regeneration of tolerant plants in linseed. Agriculture Ecosystem Environment, 61, 45-50.

Farmer, A. A., \& Farmer, A. M. (2000). Concentration of cadmium, lead, and zinc in live stock feed and organs around a metal production center in eastern Kazakstan. Science of the Total Environment, 257, 53-60.

Florence, T. M. (1982). The speciation of trace elements in water. Talanta, 29, 345-369.

Gardner, J. L., \& Al-Hamdani, S. H. (1997). Interactive effects of aluminum and humic substances on Salvania. Journal of Aquatic Plant Management, 35, 30-34.

Garvey, J. E., Owen, H. A., \& Winner, R. W. (1991). Toxicity of copper to the green algae, Chlamydomonas reinhardtii, as affected by humic substances of terrestrial and freshwater origin. Aquatic Toxicology, 19, 89-96.

Ghosh, R., \& Banerjee, D. K. (1997). Complexation of trace metals with humic acids from soil, sediment and sewage. Chemical Speciation and Bioavailability, 9(1), 15-19.

Gueguen, C., Koukal, B., Dominik, J., Pardos, M. (2003). Competition between alga (Psuedokirchneriella subcapitata) humic substances and EDTA for Cd and Zn control in algal assay procedure (AAP) medium. Chemosphere, 53, 927-934.

Hart, J. J., Welch, R. M., Noevell, W. A., \& Kochain, L. V. (2002). Transport interactions between cadmium and zinc in root bread and durum wheat seedling. Plant Physiology, $116,73-78$.

John, M. K. (1976). Interrelationships between plant cadmium and uptake of some other elements from culture solutions by oats and lettuce. Environmental Pollution, 11, 85-95.

Kabata-Pandias, A. (2000). Trace elements in soils and plants (3rd edn.) (pp. 413). Florida: CRC.

Koukal, B., Gueguen, C., Pardos, M., \& Domonik, J. (2003). Influence of humic substances on the toxic effects of cadmium and zinc to the green algae Pseudokirchneriella subcapitata. Chemosphere, 53, 953-961.

Kruatrachue, M., Jarupan, W., Chitramwong, Y. P., Pokethitiyook, P., Upatham, E. S., \& Parkpoomkamol, K. (2002). Combined 
effects of lead and humic acid on growth and lead uptake of duckweed, Lemna minor. Bulletin of Environmental Contamination and Toxicology, 69, 655-661.

Lagerwerff, J. V., \& Biersdorf, G. T. (1972). Interaction of zinc with uptake and translocation of cadmium in radish. In D. D. Hemphill (edn.), The Trace Substances in Environmental Health (vol. 5, pp. 515-522). Columbia: University of Missouri.

Linnik, D. M. (2000). Zinc, lead, and cadmium speciation in Dnieper water-bodies lake reservoirs. Resource Management, 5, 261-270.

McKenna, I. M., Chaney, R. L., \& Williams, F. M. (1993). The effects of cadmium and zinc interactions on the accumulation and tissue distribution of zinc and cadmium in lettuce and spinach. Environmental Pollution, 79, 113-120.

Nan, Z., Li, J., Zhang, J., \& Cheng, G. (2002). Cadmium and zinc interactions and their transfer in soil-crop system under actual field conditions. Science Total Environment, 285, 187-195.

Ornes, W. H., \& Sajwan, K. S. (1993). Cadmium accumulation and bioavailability in coontail (Ceratophyllum demersum) plants. Water, Air, and Soil Pollution, 69, 291-300.

Pichtel, J., Kuroiwa, K., \& Sawyer, H. T. (2000). The distribution of lead, cadmium and barium in soils and plants of two contaminated sites. Environmental Pollution, 110, 171-178.

Rai, U. N., Sinha, S., Tripathy, R. D., \& Chandra, P. (1995). Wastewater treatability potential of some aquatic macro- phytes: Removal of heavy metal. Ecological Engineering, $5,5-12$.

Srivastava, G. K., \& Singha, V. P. (1989). Uptake accumulation and translocation of cadmium and zinc in Albelmoschus esculentus L. Moench. Plant Physiology \& Biochemistry, $16,17-22$.

Stevenson, F. J. (1994). Humus Chemistry: Genesis, Composition, Reactions (288 pp). New York: Wiley.

Thurman, E. M. (1985). Organic geochemistry of natural waters (497 pp). Boston: Martinus Nijhoff/Dr W Junk.

Tipping, E. (2002). Cation binding by humic substances (434 pp.). Cambridge: Cambridge University Press.

Tubbing, D. M. J., Admiral, W., Cleven, R. F. M. J., Iqbal, M., Van de Meet, D., \& Verweij, W. (1994). The contribution of complex copper to the metabolic inhibition of algae and bacteria in synthetic media and river water. Water Research, 28, 37-44.

Turner, M. A. (1973). Effects of cadmium treatment on cadmium and zinc uptake by selected vegetables. Journal of Environmental Quality, 2, 118-119.

Velthorst, E., Nakken-Brameijer, N., \& Mulder, J. (1999). Fractionation of. soil organic matter. International Journal of Environmental Analytical Chemistry, 73, 237.

Wajda, L., Kutemozinska, W., \& Pilipowiez, M. (1989). Cadmium toxicity to plant callus culture in vitro. I Modulation by zinc and cadmium dependent on plant species and callus line. Environmental and Experimental Botany, 29, 301-305. 